\title{
Geochemical of Karst Water in the Western part of Gunungkidul District Area
}

\author{
T. Listyani R.A ${ }^{\mathrm{a},{ }^{*}}$, Dianto Isnawan ${ }^{\mathrm{a}}$ \\ ${ }^{a}$ Geological Engineering, Institut Teknologi Nasional Yogyakarta, Jl. Babarsari, Yogyakarta 55281, Indonesia \\ Correspondng author: *listyanitheophila@gmail.com
}

\begin{abstract}
The geological condition of the study area is included in the karst of the Panggang hydrogeological subsystem. This karst area is characterized by the presence of surface water and groundwater, which is distinctive, where the water is interesting to be studied, especially on its hydrochemistry. By knowing hydrochemistry, this research wants to know about the relationship between surface water and groundwater. The method was a hydrogeological survey and accompanied by hydrochemical testing of dolines (surface) water and groundwater. The data have been analyzed by some hydrochemical diagrams such as Schoeller, Piper, Durov, and Collins diagrams. Springs emerge from reef limestone aquifers (Gunungsewu aquifers) in several places, supported by grains, fractures, and channels porosities. Both groundwater and surface water are colorless (46 - 350 TCU) and clear ( 3 - 19 NTU) with a pH of 6.8 - 8.1 and TDS 76 - 308 ppm. Groundwater shows the $\mathrm{Ca}$ - bicarbonate and $\mathrm{Ca}$, $\mathrm{Mg}$ - bicarbonate types, whereas dolines (surface) water has $\mathrm{Ca}$, Mg - bicarbonate types. Groundwater and surface water show relatively similar hydrochemical facies. Enrichment of hydrochemical groundwater is greater in springs than in dolines. The doline water may not correlate with each other, and it means that the groundwater flows to dolines maybe not be interconnected. Thus, water in the karst area may flow in all directions, depending on the porosity of the controlling channels. Water in the study area is young, indicated by the $\mathrm{Ca}^{2+}$ and $\mathrm{HCO}_{3}^{-}$dominant ions, supported by ion exchange and simple dissolution processes.
\end{abstract}

Keywords - Surface water; groundwater; relation; hydrochemical; karst.

Manuscript received 10 Jun. 2020; revised 15 Sep. 2020; accepted 6 May 2021. Date of publication 30 Jun. 2021. IJASEIT is licensed under a Creative Commons Attribution-Share Alike 4.0 International License.

\section{INTRODUCTION}

This hydrogeological study was carried out in the Panggang and surrounding areas, Gunungkidul Regency (Figure 1). The study area is in the western part of the Southern Mountains physiographic zone [1], specifically the Gunungsewu sub-zone. Panggang and surrounding areas are part of the karst region [2], famous as the Gunungsewu Karst Landscape Area. In general, the karst zone has its peculiarities, especially in terms of water resources [3]. This area is a landscape that has a unique geological component and functions as a natural control of the water system, so it needs to be preserved and protected. Therefore, hydrogeological research needs to be done to support the sustainability of the landscape in the study area.

The potential of groundwater in the western part of the Gunungkidul area can be assessed using the hydrochemical method. This method will help the understanding of an area's hydrogeology. By knowing groundwater chemistry, we can conduct various analyses, interpretations, and groundwater geology correlations.

Hydrochemical studies will help to understand the hydrogeological model. Therefore, a good study of the hydrochemical of the area is needed. The geology of an area controls various hydrochemical processes. By knowing the hydrochemical groundwater, we can determine the various processes during groundwater flowing beneath the earth's surface. Thus, the hydrogeological model can be approached by looking at the diversity of groundwater chemical types. Groundwater hydrochemistry is also useful to see groundwater quality potential, which is undoubtedly very useful for people who live in the study area.

Understanding hydrochemical characteristics are useful for knowing flow type [4]. Preliminary research has been done in Petoyan spring. This spring is one of the most important springs in the western part of the Gunungsewu karst area. Based on hydrogeochemical, the correlation between the diffuse flow and a major proportion of dissolved elements during the flood recession periods was strong because the 
conduit flow domination was replaced by the diffuse flow, causing the domination of water-rock interaction. According to the diffuse flow and its relation to its hydrochemistry, it is apparent that small fractures in the Petoyan Spring aquifer still provide adequate storage for the diffuse flow, even though the conduit fracture has already been developed.

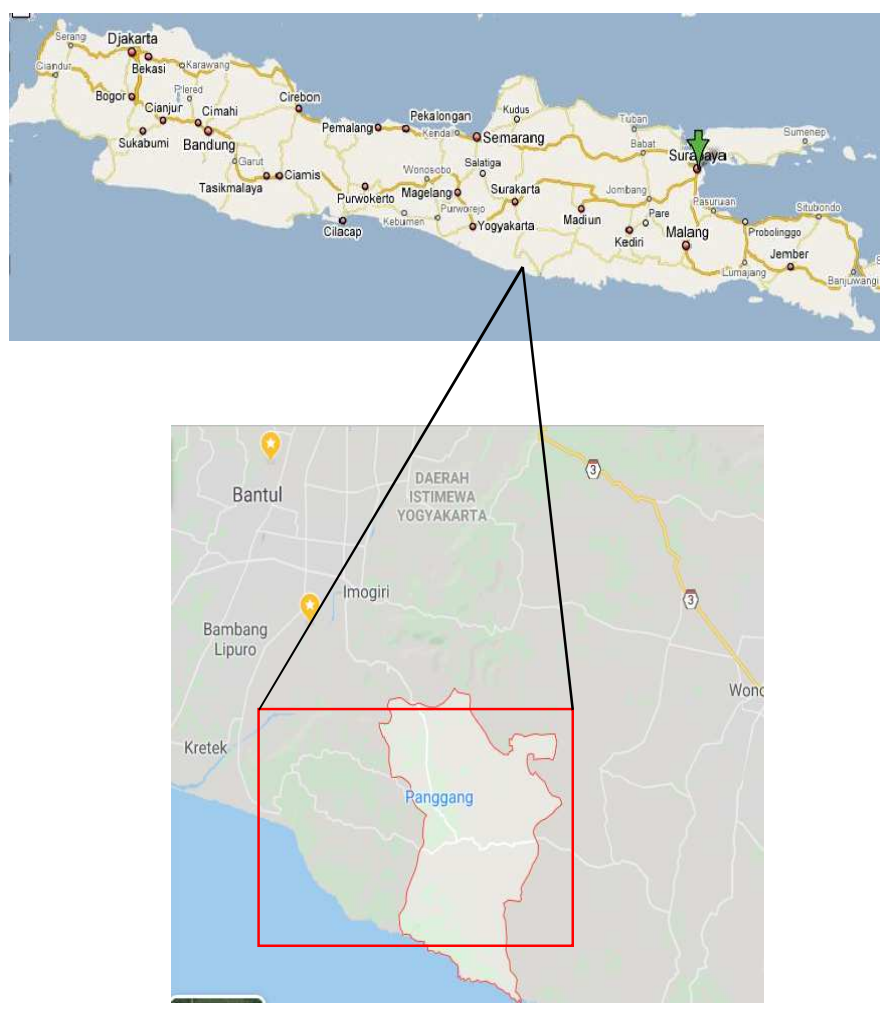

Fig. 1 The location of the research area.

The system voids in the Petoyan Spring discharge performed a rapid response to rainfall because the conduit system is already developed. The rapid response is also shown by the highest correlation between rainfall and discharge. The Petoyan Spring has diffused, fissure, and conduit flow components. However, the percentage of monthly diffuse flow still shows the dominance of the diffuse flow in the karst aquifers [5].

\section{MATERIALS AND METHOD}

The hydrogeological survey has been carried out in the field by geological and hydrochemical ( $\mathrm{pH}, \mathrm{TDS}$ ) equipment. Four water samples originating from springs and dolines were taken and tested for their physical/chemical characteristics in the BBTKLP Yogyakarta laboratory. Furthermore, field and laboratory data analysis has been carried out to obtain an interpretation of the hydrochemical processes. The interpretation is made by the Kurlov classification, Stiff \& Schoeller correlation, Piper \& Durov analysis, and Collins bar synthesis methods.

\section{RESULTS AND DISCUSSION}

\section{A. Geology of Gunungsewu}

The morphology of the research area includes the western part of the Gunungsewu karst sub physiography, the Southern Mountains physiography [1]. The Gunungsewu karst region landscape is unique, characterized by the presence of phenomena on the surface (exokarst) and subsurface (endokarst). In the research area, the exokarst phenomenon is shown by conical hills and dolines scattered in several places.

A geological field survey has been carried out in areas included in the Panggang and its vicinity. The research area includes several villages in the Purwosari and Panggang Subdistricts, included in the Panggang topographic map. This area is generally a manifestation of the karst hills with unique conical hills (Figure 2), moderate relief, and some dolines /karst lake appearances that form exokarst. The pain relief is only found in narrow areas. There is no surface water/river flow in the research area, and groundwater usually emerges locally as a spring.

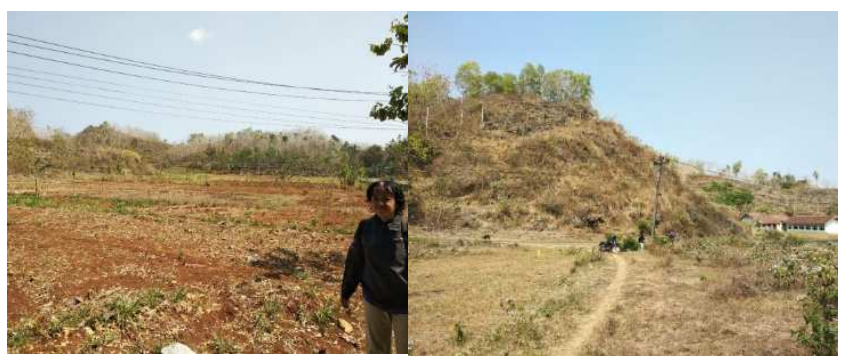

Fig. 2 Karst morphology at Panggang area

Karst springs generally occur due to the geological conditions dominated by soluble carbonate rocks and intensive geological structures. Characteristics of groundwater infiltration area can be determined based on the analysis of the partial pressure of $\mathrm{CO}_{2}, \mathrm{CaCO}_{3}$ saturation index (SIc), facies of groundwater chemistry, and lineaments of morphology. Differences in the infiltration capacity of the area are also characterized by differences in groundwater hydrochemical facies [6]. Gunungsewu karst hills have a bedrock of volcanic products comprising Kebo-Butak, Semilir, and Nglanggran Formations. Above these volcanic rocks, locally, particularly in the Panggang area, found marl of Sambipitu Formation. Marl and volcanic rocks are impermeable so that they can act as the bedrock in Gunungsewu hydrogeological system [7].

Based on Yogyakarta's regional geological map, the study area comprises the Wonosari Formation [2]. This formation is composed of reef limestone, calcarenite, and tuffaceous limestone. In the field, reef features are shown by massive limestone with lapies morphology (Figure 3). In addition to massive rocks, there are found some thick layers of limestone and also tuffaceous limestone.

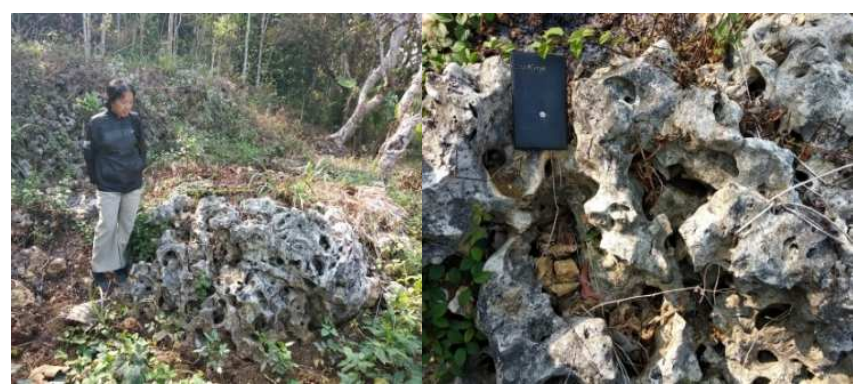

Fig. 3 Massive limestone with lapies morphology in the research area

Geological data is collected through observations at several locations, as presented in Table 1 and Figure 4. Descriptions 
were made of rocks and geological conditions at each stop site. The studied area is included in the Panggang Hydrogeological Subsystem [8]. This subsystem is located in the western part of the Gunung Sewu Hydrogeological System. The aquifer layer in the karst region is generally very complicated and not easy to detect. Panggang Subsystem is composed of limestone reefs which include boundstone and packstone. The surface flow is not found on this subsystem. In this region, the free aquifer has a thickness of 50-100 m, where groundwater is discharged through springs with a discharge less than 100 $1 /$ sec. Springs are formed by the contact of limestone aquifer with the bedrock of volcanic rocks (tuffaceous sandstones, breccias, and lava). This subsystem has an area of approximately $215 \mathrm{~km}^{2}$.
TABLE I

LOCATION DATA OF RESEARCH OBSERVATIONS OF PANGGANG AND SURROUNDING AREAS

\begin{tabular}{llcl}
\hline No & \multicolumn{1}{c}{ Location } & Longitude (S) & Latitude (E) \\
\hline S1 & Galis cave, Karangtengah & $08^{\circ} 01^{\prime} 40.2^{\prime \prime}$ & $110^{\circ} 22^{\prime} 03.0^{\prime \prime}$ \\
S2 & Gembirowati temple & $08^{\circ} 00^{\prime} 56.2^{\prime \prime}$ & $110^{\circ} 20^{\prime} 25.3^{\prime \prime}$ \\
S3 & Jambu (Purwosari) spring & $07^{\circ} 59^{\prime} 43.0^{\prime \prime}$ & $110^{\circ} 20^{\prime} 47.4^{\prime \prime}$ \\
D4 & Bembem doline (Giriasih) & $07^{\circ} 59^{\prime} 33.9^{\prime \prime}$ & $110^{\circ} 21^{\prime} 43.1^{\prime \prime}$ \\
S5 & Pego cave (Ngoro-oro) & $07^{\circ} 59^{\prime} 56.6^{\prime \prime}$ & $110^{\circ} 22^{\prime} 14.1^{\prime \prime}$ \\
S6 & Petoyan spring, Purwosari & $07^{\circ} 59^{\prime} 52.3^{\prime \prime}$ & $110^{\circ} 22^{\prime} 48.6^{\prime \prime}$ \\
S7 & Cerme cave (Imogiri) & $07^{\circ} 58^{\prime} 46.6^{\prime \prime}$ & $110^{\circ} 22^{\prime} 50.7^{\prime \prime}$ \\
D8 & Dendengwelut doline & $08^{\circ} 09^{\prime} 49.2^{\prime \prime}$ & $110^{\circ} 25^{\prime} 28.9^{\prime \prime}$ \\
D9 & Towet doline (Girisekar) & $08^{\circ} 02^{\prime} 1.40^{\prime \prime}$ & $110^{\circ} 28^{\prime} 04.3^{\prime \prime}$ \\
\hline
\end{tabular}

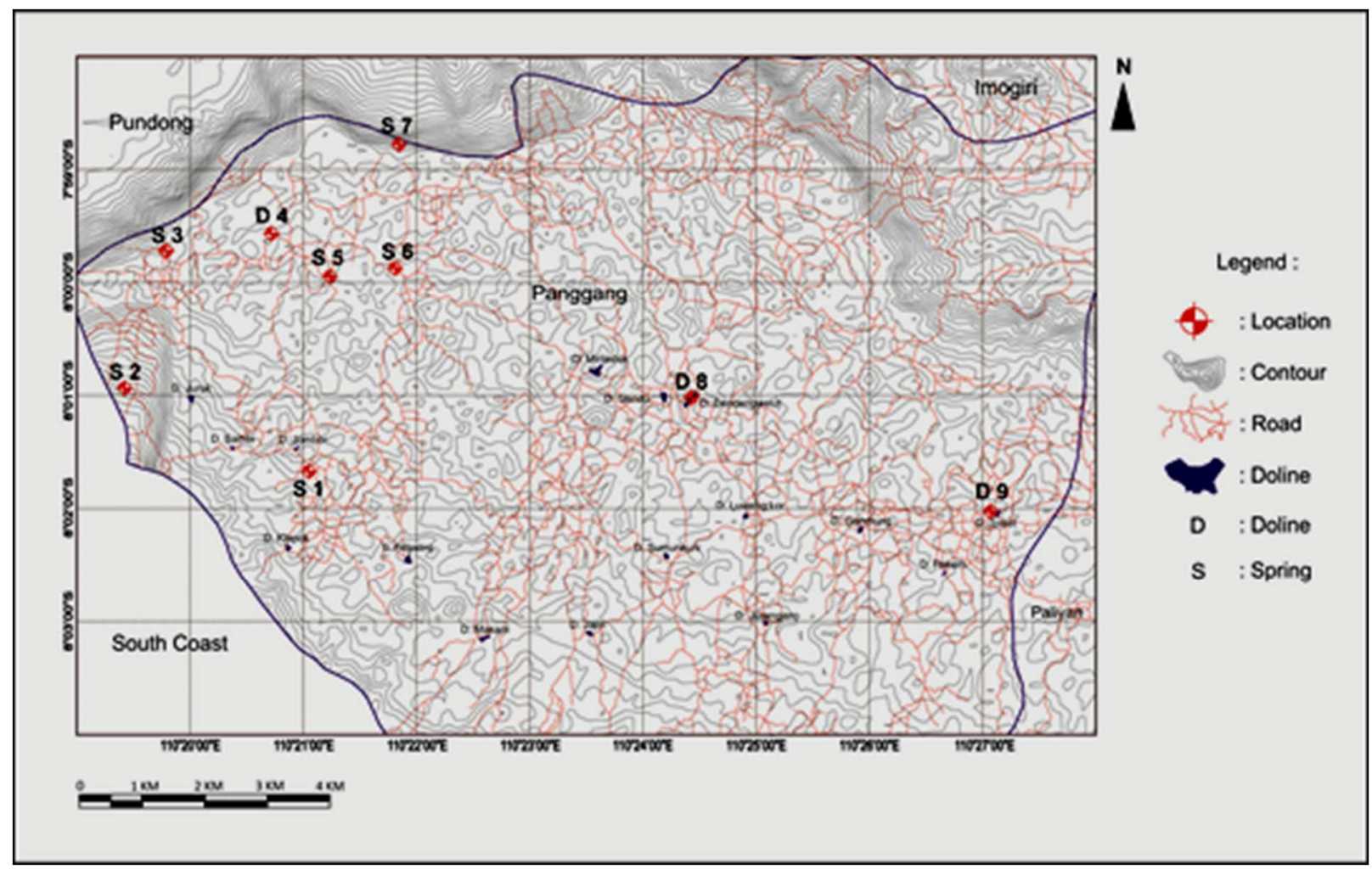

Fig. 4 Observed location of the research area

The karst area in Panggang Subsystem has specific hydrogeological properties, including predominant epikarst springs with minimum discharge in dry seasons [9]. Flow moving slowly (infiltration), known as the steady flow or baseflow, is the only water supplier in underground flows during the dry season. The low flow rate is one of the characteristics of the emergence of springs in the area. During the rainy season, the direct flow has a greater contribution to reducing the proportion of the baseflow component [10].

Surface water infiltrates into the soil and rocks through cracks, joints and dissolving cavities and is often accelerated by lake/doline and valley media. Generally, lakes in the study area are doline morphology formed in valleys between conical hills. Two of the dolines can be seen in Figure 5.

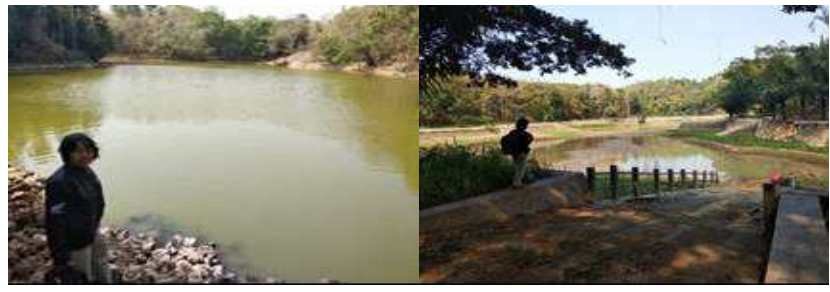

Fig. 5 Towet (left) and Dendengwelut (right) dolines; two examples of the exokarst at the research area

Karst development level of aquifer influences the rechargedischarge characteristics of groundwater. Karst aquifer with a high degree of karstification will have a fast water discharge system. Otherwise, the karst aquifer, which has a low degree of karstification, will be dominated by the diffuse flow type and a slow discharge system [11]. 


\section{B. Hydrochemical Characteristic}

1) Physical Properties of Water: The physical properties of groundwater include colour, odour, taste, viscosity, turbidity, and $\mathrm{pH}$ (acidity). In the field, groundwater tends to be colorless, relatively clear - sometimes rather turbid. Likewise, water in doline sometimes has a slightly greenish color. The laboratory test results show that the turbidity ranges from 3-19 NTU (Table 2). In general, surface water is more turbid than groundwater. Smell and taste cannot be identified in the field or the laboratory.

TABLE II

PHYSICAL/CHEMICAL LABORATORY OF WATER SAMPLES

\begin{tabular}{clcccc}
\hline & & \multicolumn{2}{c}{ Spring } & \multicolumn{2}{c}{ Doline } \\
\cline { 3 - 6 } No & Parameter & $\begin{array}{c}\text { S2 } \\
\text { Gembiro- } \\
\text { wati }\end{array}$ & $\begin{array}{c}\text { S5 } \\
\text { Pego }\end{array}$ & $\begin{array}{c}\text { D8 } \\
\text { Dendeng- } \\
\text { welut }\end{array}$ & $\begin{array}{c}\text { D9 } \\
\text { Towet }\end{array}$ \\
\hline 1 & $\mathrm{Ca}^{2+}(\mathrm{mg} / \mathrm{l})$ & 54.87 & 91.25 & 27.86 & 15.92 \\
2 & $\mathrm{Mg}^{2+}(\mathrm{mg} / \mathrm{l})$ & 16.36 & 11.97 & 8.22 & 7.74 \\
3 & $\mathrm{Na}^{+}(\mathrm{mg} / \mathrm{l})$ & 10 & 13 & 8 & 15 \\
4 & $\mathrm{~K}^{+}(\mathrm{mg} / \mathrm{l})$ & 1 & 1 & 6 & 4 \\
5 & $\mathrm{Cl}^{-}(\mathrm{mg} / \mathrm{l})$ & 8 & 9 & 7.0 & 4.0 \\
6 & $\mathrm{HCO}^{-}(\mathrm{mg} / \mathrm{l})$ & 259.7 & 289.9 & 146.4 & 103.7 \\
7 & $\mathrm{SO}_{4}^{2-}(\mathrm{mg} / \mathrm{l})$ & 3 & 2 & 6 & 6 \\
8 & $\mathrm{pH}$ & 7,3 & 6,8 & 7.7 & 7.3 \\
9 & $\mathrm{TDS}(\mathrm{mg} / \mathrm{l})$ & 274 & 308 & 104 & 76 \\
10 & Turbidity & 3 & 3 & 19 & 4.8 \\
\hline
\end{tabular}

2) Physical Properties of Water: The chemical properties of groundwater include hardness, TDS, electrical conductivity, acidity, and ion contents. The field data in Dendengwelut Doline show a $\mathrm{pH}$ value of 7.0, TDS of 127 ppm and EC of $170 \mu \mathrm{S}$. Meanwhile, water in Towet Doline has a $\mathrm{pH}$ of 8.1 , TDS of $94 \mathrm{ppm}$, and EC of $169 \mu \mathrm{S}$. Laboratory data show a $\mathrm{pH}$ value of 6.8 to 7.7. Thus, the acidity of the water, both groundwater and surface water, in the study area is neutral. Slightly alkaline conditions in doline water can be affected by detergent or pesticide pollution since the dolines are used for washing or farming around them.

\section{Hydrochemical Analysis}

1) Kurlov Classification: According to Kurlov's classification, the groundwater shows $\mathrm{Ca}$ - bicarbonate and $\mathrm{Ca}$, $\mathrm{Mg}$ - bicarbonate facies, while both doline water samples show $\mathrm{Ca}, \mathrm{Mg}$ - bicarbonate types (Table 3). $\mathrm{Ca}, \mathrm{Mg}$ bicarbonate type is the dominant water type in the karst area, especially in the Panggang hydrogeology subsystem.

$\mathrm{Ca}^{2+}$ ions come from dissolving dolomite or calcite in limestone, whereas $\mathrm{Mg}$ ions can be supplied from dolomite dissolution. Meanwhile, the bicarbonate anion can be obtained from $\mathrm{CO}_{2}$ from the atmosphere and soil and the dissolution of limestone and $\mathrm{CaCO}_{3}$ precipitation. However, a low TDS and $\mathrm{Ca}^{2+}$ contents of $<100 \mathrm{ppm}$ indicate that rainwater is still a major contributor to the water's chemical composition. It might also be related to limestone dissolution, which has not been intensively related to a short water journey.
TABLE III

HYDROCHEMICAL FACIES ACCORDING TO KURLOV CLASSIFICATION

\begin{tabular}{lrrrr}
\hline \multirow{2}{*}{\multicolumn{1}{c}{ Parameter }} & \multicolumn{4}{c}{ Percentage (epm) } \\
\cline { 2 - 5 } & \multicolumn{1}{c}{ S2 } & \multicolumn{1}{c}{ S5 } & \multicolumn{1}{c}{ D8 } & \multicolumn{1}{c}{ D9 } \\
\hline $\mathrm{Na}^{+}$ & 5.835 & 5.622 & 8.08 & 19.29 \\
$\mathrm{~K}^{+}$ & 0.992 & 0.735 & 10.31 & 8.748 \\
$\mathrm{Ca}^{2+}$ & 62.47 & 76.99 & 54.9 & 39.94 \\
$\mathrm{Mg}^{2+}$ & 30.71 & 16.65 & 26.71 & 32.02 \\
$\mathrm{Total}^{-}$cations & 100 & 100 & 100 & 100 \\
$\mathrm{Cl}^{-}$ & 4.966 & 5.031 & 7.255 & 5.825 \\
$\mathrm{SO}_{4}^{2-}$ & 1.374 & 0.825 & 4.589 & 6.448 \\
$\mathrm{HCO}_{3}{ }^{-}$ & 93.66 & 94.14 & 88.16 & 87.73 \\
Total anions $^{2}$ & 100 & 100 & 100 & 100 \\
Hydrochemical Facies & $\mathrm{Ca}, \mathrm{Mg}$ & $\mathrm{Ca}$ & $\mathrm{Ca}, \mathrm{Mg}$ & $\mathrm{Ca}, \mathrm{Mg}$ \\
& \multicolumn{4}{c}{$\mathrm{HCO}_{3}$ (bicarbonate) } \\
\hline
\end{tabular}

2) Stiff \& Schoeller Correlation Method: Groundwater flow patterns in the Panggang Hydrogeological Sub-system in the western part tend to be radially directed [3]. There is no groundwater flow direction data for the eastern part of this zone. Referring to the map, groundwater at the S2 and S5 springs may flow from the same area at the east of $\mathrm{S} 2$ or south of S5. The dolines water in D8 and D9 can be supplied from the higher places in the north and the surrounding groundwater supply.

The stiff diagram can be useful to correlate groundwater quality horizontally in the aquifer and know the hydrochemical facies [12]. Therefore, the characteristic of groundwater facies is useful to understand the hydrogeological system [13]. In the study area, aquifers were formed by limestone of Wonosari Formation. These aquifers can develop as shallow to the deep aquifer. However, the aquifer layer in the karst region is generally very complicated and not easy to detect. The Panggang Subsystem is occupied by reef limestone, characterised by the absence of surface runoff and the presence of free aquifers with a thin to moderate thickness [3]. The Stiff diagram shows that the hydrochemical enrichment of groundwater is greater in springs than in dolines (Figure 6). Suppose that the aquifer carrying water in the spring and doline is one of the same aquifer zones. This indicates that doline water is more influenced by local rainfall so that the concentration is relatively low.

The Schoeller diagram also represents the same thing as the Stiff one (Figure 7). The diagram shows that springs tend to show more chemical composition water than dolines. Suppose the groundwater flow pattern tends to the east in the eastern part of the Panggang Subsystem, then, of course, the chemical composition of D9 is richer than that of D8. However, the dominant cation $\left(\mathrm{Ca}^{2+}\right)$ and TDS of doline water D8 are richer than D9. Therefore, the two surface types of water may not correlate with each other, or in other words, the groundwater flow that supplies doline is not interconnected. This opinion supports that water in the karst area can travel in all directions, depending on the porosity of the channel that controls it. 


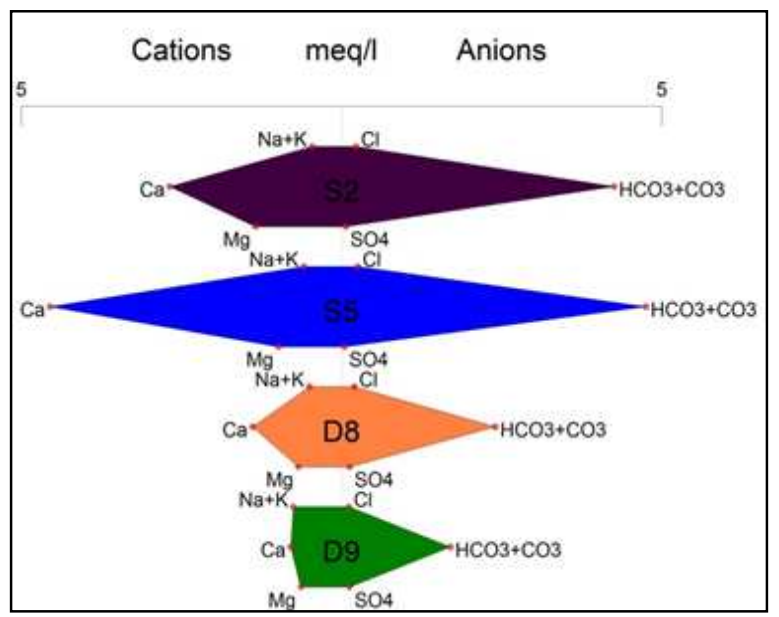

Fig. 6 Stiff diagram of groundwater and surface water

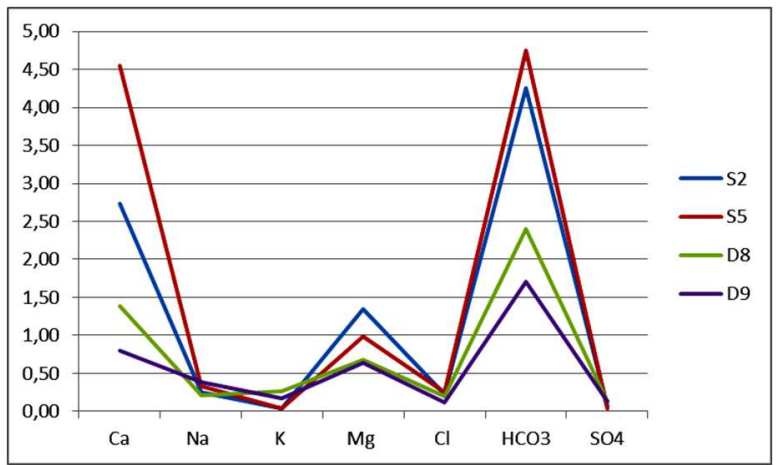

Fig. 7 Schoeller diagram for groundwater and doline water in the research area

3) Piper \& Durov Analysis Method: Piper's diagram (Figure 8) shows that the groundwater in the spring is freshwater, where the leaching process becomes dominant in this groundwater flow process. Plotting the water chemistry data in the Durov diagram (Figure 9) shows that the four groundwater samples entered the area with the dominant ion exchange and simple dissolution processes. Water in this area has a dominant $\mathrm{HCO}_{3}{ }^{-}$anion. The dominant $\mathrm{Ca}^{2+}$ contents usually show association with carbonate minerals in limestone.

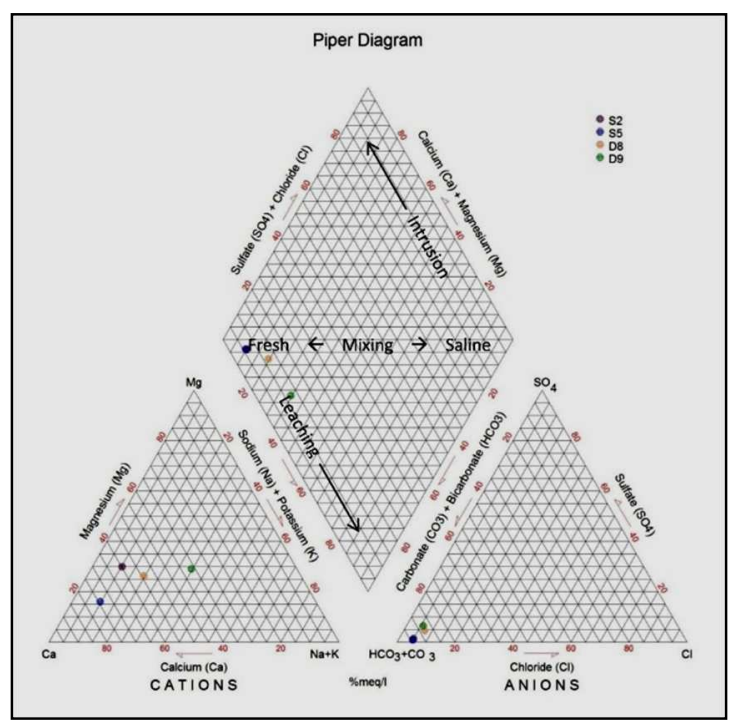

Fig. 8 Plot data at the Piper diagram indicates leaching and mixing as dominant processes

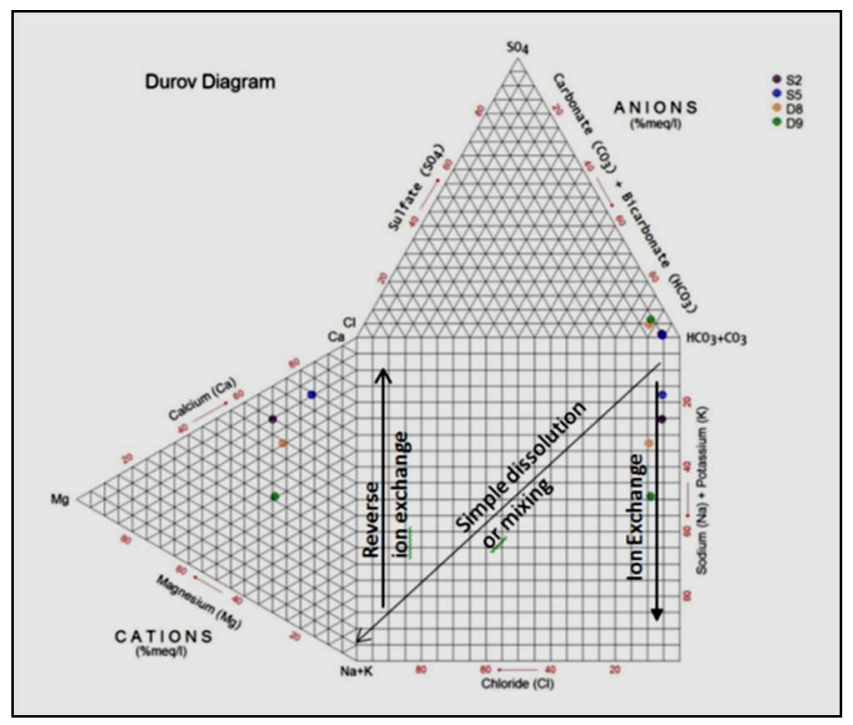

Fig. 9 Plot data in the Durov diagram show ion exchange and simple dissolution as dominant processes

Groundwater/surface water in the study area is young, indicated by the dominant $\mathrm{Ca}^{2+}$ and $\mathrm{HCO}_{3}^{-}$ions. This groundwater generally comes from areas that are not far from the recharge zone, or the study area is still a catchment zone of the Panggang Subsystem.

4) Collins Bar Synthesis Method: The Collins bar chart of water shows moderate amounts of cations and anions and the amount of silica content. Figure 10 shows that cation and anion in doline water are relatively less than their groundwater content in springs. This result shows that groundwater has more interaction with aquifer rock minerals in springs or has a longer flow path and longer travel time.

Based on several previous interpretations, the synthesis of genetic water in the study area can be taken by its hydrochemical characteristics. Groundwater in the karst system formed by limestone flows through the aquifer system with porosities between the grains, cracks or channels. This finding indicates that groundwater may flow locally or on a regional system, but it is difficult to determine upstream/downstream flow.

Mixing between local or regional groundwater recharge in Gunungsewu karst hills can be seen from the groundwater flow pattern, which generally moves from north (Wonosari plain) to south (karst hills) [14]. The groundwater flow pattern was evident in the Wonosari - Baron subsystem but still unknown in the Panggang subsystem because of no supporting data [8].

The hydrochemical evolution is difficult to determine through flow patterns. Groundwater from spring or surface/doline water may be interconnected or may not correlate at all. The same limestone aquifers determine similarities in hydrochemical characteristics. The concentration that tends to be lower in doline water shows that the source of surface water is still dominated by rainwater. Unlike groundwater flow in volcaniclastic rocks that are generally controlled by morphology [15], groundwater flow in karst areas is generally controlled by cracks and conduits. 


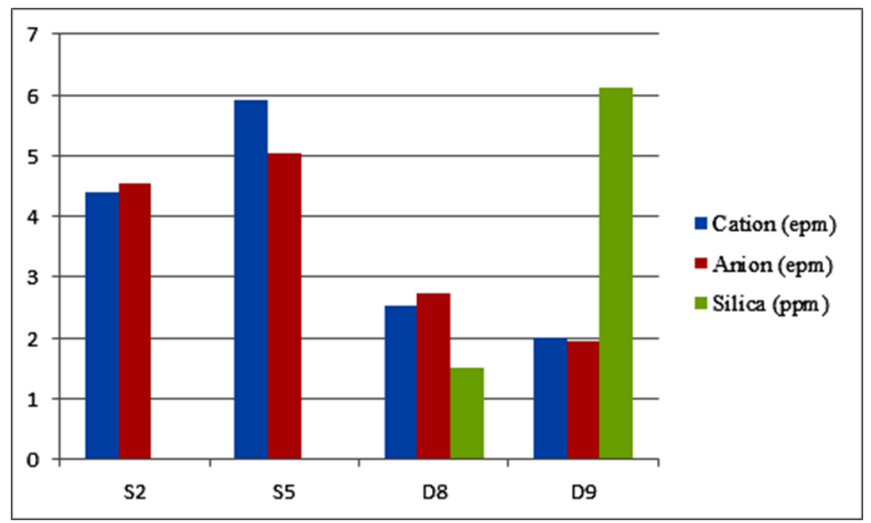

Fig. 10 Collins bar diagram indicates a low concentration of water at dolines compared with springs

The conceptual model of water flow in the research area can be seen in Figure 11. The water in Dolina is supported by rainfall and underground flow, which is not always connected to groundwater in the spring. Groundwater in the karst limestone of the Wonosari Formation can flow through underground cavities and emerge as a spring. Meanwhile, tuffaceous sandstones and other volcanic products from the Sambipitu and Nglanggran Formations can act as an impermeable layer of the karst groundwater basin.

Units of landform may distinct the hydrogeochemical facies [16], where not all processes may occur, each landform dominantly. The research area shows ion exchange and simple dissolution as the dominant hydrogeochemical processes in the karst region. These processes may also be supported by soil and rocks materials. As unique features of the karst landscape, the dolines are usually characterized by medium texture soil with fine clay attributes [17]. This petrophysics may influence the porosity and permeability of land cover and support ion exchange as well as simple dissolution processes. Petrophysical rock certainly affects the hydraulic conditions of the aquifer [18]. Thus, aquifer conditions will support various hydrochemical processes.

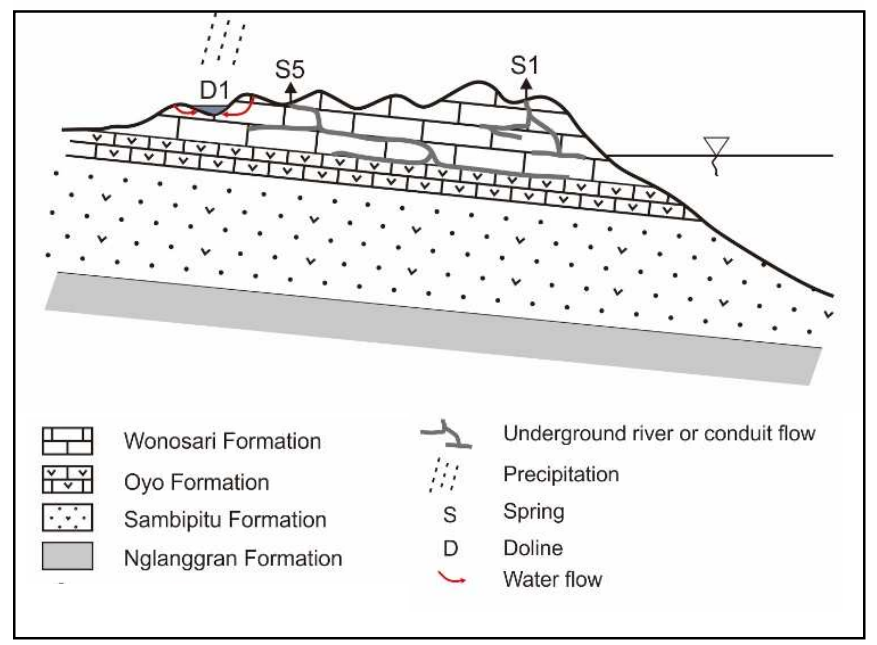

Fig. 11 Interpretation of the kars groundwater flow model; water in the doline is not connected to groundwater in springs.

\section{CONCLUSION}

The research area is part of the karst area, which is located at the Panggang Hydrogeological Subsystem. The karst landscape is characterized by the characteristics of conical hills and several dolines. Groundwater emerges in several places as springs of reef limestone aquifers, supported by intergrain, fractures, and channels porosities. Groundwater and surface water are colourless (46 - 350 TCU) and relatively clear (3 - 19 NTU) with a pH of $6.8-8.1$ and TDS of $76-308$ ppm. Groundwater shows $\mathrm{Ca}-$ bicarbonate and $\mathrm{Ca}, \mathrm{Mg}-$ bicarbonate types, whereas dolines water has $\mathrm{Ca}, \mathrm{Mg}$ bicarbonate types. The water shows relatively similar hydrochemical facies. The Stiff diagram shows that the hydrochemical enrichment of groundwater in the karst aquifer is greater in springs than in dolines. The analysis of the Stiff and Schoeller diagram shows that surface water may not correlate with each other. It means that the groundwater flows to dolines may not be interconnected. Thus, the water in the karst system can run in all directions depending on the porosity of the conduits that control it. The groundwater in the study area is young, indicated by the dominant $\mathrm{Ca}^{2+}$ and $\mathrm{HCO}_{3}{ }^{-}$ions, supported by ion exchange and simple dissolution processes.

\section{ACKNOWLEDGEMENT}

This paper was prepared as a result of ITNY internal research. Therefore, we would like to thank ITNY for the funding support for this research.

\section{REFERENCES}

[1] R.W. Van Bemmelen, The Geology of Indonesia, Vol. 1A, Martinus Nijhoff, The Hague, Netherland, 1949.

[2] W. Raharjo, Sukandarrumidi, and H.M.D. Rosidi, Peta Geologi Lembar Yogyakarta, Jawa, Scale $1: 100.000$. Pusat Penelitian dan Pengembangan Geologi, Bandung, 1995.

[3] D. Isnawan, T. Listyani R.A., and F. Noormansyah, "Environmental Geological Potential of Kaligesing Area, Purworejo District". KURVATEK, Vol. 2, No. 2, pp.11-23, Nov. 2017.

[4] T.N. Adji, E.Haryono, H. Fatchurohman, R. Oktama, "Diffuse Flow Characteristics and Their Relation to Hydrochemistry Conditions in The Petoyan Spring, Gunungsewu Karst, Java, Indonesia", Geosciences Journal, Vol. 20, No. 3, pp. 381-390, The Korean Association of Societies and Springer Geoscience, DOI 10.1007 / s12303-015-0048-8, 2016.

[5] T.N. Adji and I.Y.Bahtiar, "Rainfall-Discharge Relationship and Karst Flow Components Analysis for Karst Aquifer characterisation in Petoyan Spring, Java, Indonesia", Environ Earth Sci., 75: 735. DOI 10.1007 / s12665-016-5553-1, 2016.

[6] N.M.A. Asghaf, B.Y.C.S.S. Alam and Hendarmawan, "Characteristic Identification of Groundwater Infiltration Areas Based on the $\mathrm{CO}_{2}$ Partial Pressure and the Calcite Saturation Indices (SIc) in Watuputih Karst Hills", Journal of Environment and Geological Hazards, Vol. 10, No. 2, pp. 27-39, 2019.

[7] S.B. Kusumayudha, Hidrogeologi Karst dan Geometri Fraktal di Daerah Gunungsewu, Adicita Karya Nusa, Yogyakarta, 2005.

[8] S.B. Kusumayudha, "Sistem Hidrogeologi Gunung Sewu", in Proc. Sumberdaya Geologi Daerah Istimewa Yogyakarta dan Jawa Tengah, Ikatan Ahli Geologi Indonesia, Pengurus Daerah DIY - Jateng, Yogyakarta, 2002.

[9] I.A. Riyanto, A. Cahyadi, D. Sismoyo, M. Naufal, F. Ramadan, M. Widyastuti, and T.N. Adji, "Installation of Deep Groundwater Wells as Solution to Water Resources Problem in Panggang Subsystem, Gunungsewu Karst Area, Indonesia”, in Proc. ICENIS 2019, E3S web of Conferences 125, 01009.

[10] M. Naufal, M. Widyastuti, A. Cahyadi, F. Ramadan, I.A. Riyanto, K.S.T.A. Nisa, T.N. Adji, E. Haryono, "Temporal Variations of Baseflow Contribution to Epikarst Spring Discharge in Gunungsewu Karst Area, Indonesia", in Proc. ICENIS 2019, E3S web of Conferences 125, 01014 .

[11] T.N. Adji, M.A. Mujib, H. Fatchurohman, I.Y. Bahtiar, "Analisis Tingkat Perkembangan Akuifer Karst di Kawasan Karst Gunung Sewu, Daerah Istimewa Yogyakarta dan Karst Rengel, Tuban, Jawa Timur 
berdasarkan Analisis Hidrograf", in Proc. of $17^{\text {th }}$ IGI Annual Conference, UNY, Yogyakarta, 2015.

[12] S.N. Peni and T. Listyani R.A., "Physical and Chemical Properties of Groundwater in Banjararum Area and Its Vicinity", KURVATEK, Vol. 04, No. 2, pp. 111-116, Nov. 2019.

[13] T. Setiawan, BYCSSS Alam, E. Haryono, and Hendarmawan, "Spatio-temporal Variation of Karst Spring Parameters for Characterizing of The Aquifer System of Watuputih Area, Indonesia", Journal of Water and Land Development, No. 45 (IV-VI), pp. 143-156, 2020.

[14] T. Setiawan, S. Isnaini, N.M.A. Asghaf and I. Effendi, "Groundwater Recharge System of Wonosari - Baron Karst Area, Gunung Kidul Regency, Yogyakarta Special Region, based on Isotope Analysis of ${ }^{18} \mathrm{O}$ and ${ }^{2} \mathrm{H} "$, Journal of Environment and Geological Hazards, Vol. 9, No. 3, pp. 143-155, 2018.
[15] Ev. Budiadi, T. Listyani R.A. and C.U. Putro, "Morphological Aspects on Spring Appearance at Girimulyo and Its Surrounding Area, West Progo", KURVATEK, Vol. 02 , No. 2, pp. 45-54, Nov. 2017.

[16] R.P. Poetra, T.N. Adji, L.W. Santosa, "Hydrogeochemical Conditions in Groundwater Systems with Various Geomorphological Units in Kulonprogo Regency, Java Island, Indonesia", Aquat Geochem, https://doi.org/10.1007/s10498-020-09384-w, 2020.

[17] R.I. Haripa, A. Damayanti, and T.L. Indra, "Property Index and Hydrophysical Conditions of Soils at Subsidences in Ponjong, Rongkop and Semanu Subdistricts, Gunungkidul District", International Journal of GEOMATE, Vol.19, Issue 73, pp. 242-249, 2020 .

[18] T. Listyani R.A., "Identifikasi Petrofisik Batuan sebagai Pendukung Karakteristik Hidrolik Akuifer pada Sub DAS Code, Yogyakarta”, Jurnal Geosapta, Vol. 6, No. 2, Jul. 2020. 